\title{
Fine structure of lipotubuloids (elaioplasts) in Ornithogalum umbellatum in the course of their development
}

\author{
M. KWIATKOWSKA
}

Institute of Biochemistry and Physiology, University of Łódź, Laboratory of Plant Cytology and Cytochemistry, Łódź, Nowopołudniowa $12 / 16$, Poland

(Received: November 16, 1970)

\begin{abstract}
:
Among the most important changes in the fine structure of lipotubuloids, observed in the course of their development cycle, belong: 1) the appearance in ageing lipotubuloids of autolytic vacuoles, in which hydrolytic enzymes are present; 2) the disappearance of the microtubules forming a network and interconnecting the osmiophilic granules, which precedes the dispersion of these granules agglomerated in lipotubuloids.
\end{abstract}

\section{INTRODUCTION}

The fine structure of $O$. umbellatum lipotubuloids has been described in the previous part of this paper (Kwiatkowska, 1971). Intravital investigations showed that the cycle of development of the lipotubuloids occurs in the following sequence.

In the ovary epidermal cells there first appear aggregations of several highly refractive osmiophilic granules ca. $0.4 \mu$ in diameter. Generally there is one such agglomeration in the cell, but sometimes more may be found. The smaller groups formed merge to become one structure (fig. 1A, B). The agglomerations increase in size owing to the formation of more and more granules in them, with a gradual change in shape from irregular to almost ideally spherical. At this stage the lipotubuloids seem to be surrounded by a distinct envelope which accentuates their contour (figs. 1E,10').

In the centre of the lipotubuloids of older cells there appears a space deprived of the osmiophilic granules (fig. 1F), called by Raciborski (1895) a vacuole. A further stage preceding the final disorganisation of lipotubuloids, that is their disintegration to single granules, is the formation on their surface of minute convexities which after some time detach themselves and remain free in the cell 

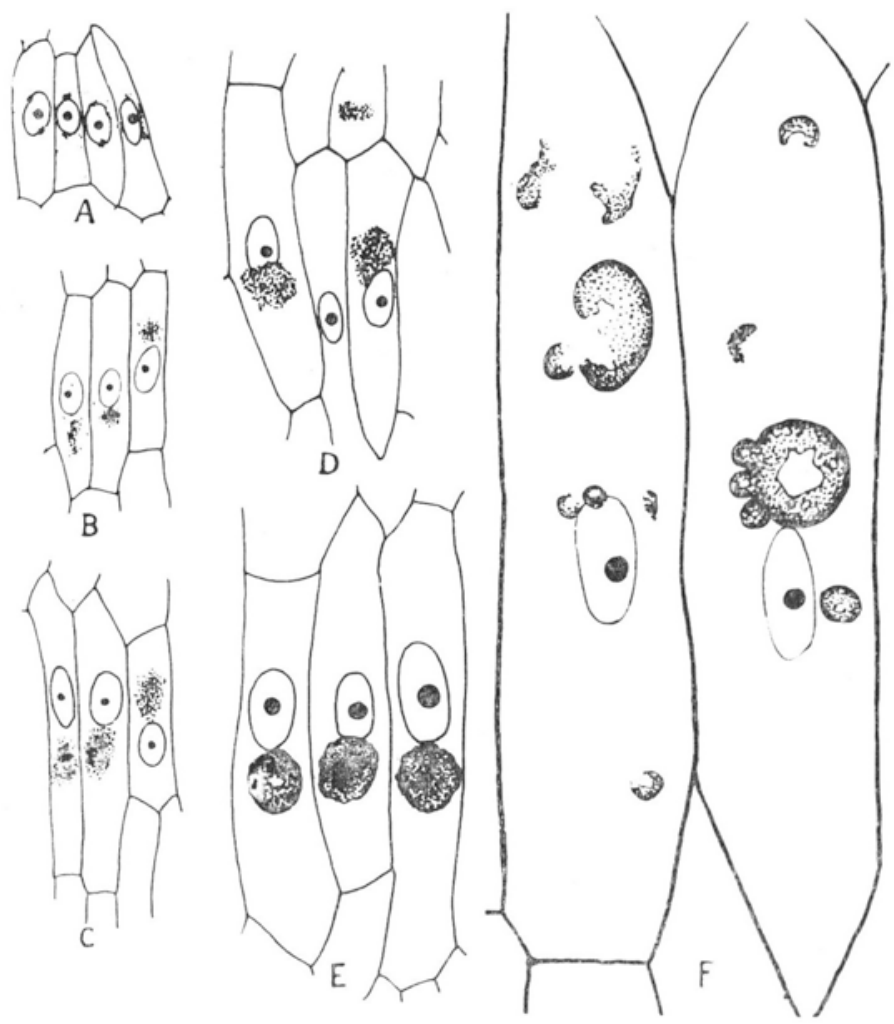

Fig. 1. O. umbellatum. Lipotubuloids in various phases of growth of ovary epidermis cells (schematically):

$A$ - formation of lipotubuloid, $B, C, D$ - lipotubuloids of irregular shape enlarging intensively, $E-$ fully formed spherical lioptubuloids, $F$ - lipotubuloids in vacuolar phase, budding and disintegration to single granules

(fig. 1F). This is referred to as "budding" of the elaioplasts (Raciborski, 1895; Politis, 1911).

The first phase of lipotubuloid development occurs in the cells of the ovary which is ca. $1 \mathrm{~mm}$ long, cream-coloured and hidden in a minute bud. Spherical lipotubuloids may be found in fully developed and pollinated flowers with drying up perianth. At this time the ovary is intensively green. The cells in fig. 1F are derived from a ca. $8 \mathrm{~mm}$ ovary which had ceased to grow and was losing its green colour before drying up. The arrangement of the cells and their shape indicate that there probably occur no more divisions in the ovary epidermis at the stage described, but that a very intensive elongation growth takes place. The surface of each of these cells is enlarged ca. 30 times $(3000 \%$ ). The highest surface area increment (ca. $2400 \%$ ) falls to the relatively short period from coming into flower to its drying up (fig. $1 \mathrm{E}$ and $\mathrm{F}$ ), lasting in dependence on weather 3 to 5 days. At this time the lipotubu- 
loids are at the peak of their development, their size is largest and their shape spherical. Only the lipotubuloids of the stomata disappear at earlier stages (K wiatkowska, 1962).

The subject of the present communication are electron microscopic studies of lipotubuloids at the above described development stages.

\section{MATERIAL AND METHODS}

The observations were made on material fixed after Palade and embedded in methacrylate. Ultrathin sections were prepared on a Freiberger Präzisionsmechanik microtome and stained with uranyl acetate. Observations were made in Tesla BS 242 and UMW 100 microscopes.

The osmiophilic granules were measured on plates obtained at a high resolving power. As criterion of the plate quality, the visibility of the microtubules was assumed. This warranted that the pictures represent sections, the thickness of which was closely similar. The granules were measured at a $\times 100000$ magnification directly on the photographic enlarger.

\section{RESULTS OF OBSERVATIONS}

The organization of lipotubuloids is essentially similar at all development stages. They are aggregations of osmiophillic granules held in a network of microtubules and connected with the latter. They are not separated from the remaining cytoplasm by their own membrane, within which scarse mitochondria and Golgi apparatus are also found (cf. Kwiatkowska, 1971). As the dimensions of the lipotubuloids increase, quantitative changes occur: the number of osmiophilic granules increases within them. The number of microtubules also increases more or less in the same proportion, since both in early and in later stages nearly every granule is in contact with several tens of microtubules.

As the lipstubuloid develops, there appear subtle differences in the cytoplasm structure and the proportions of various-sized osmiophilic granules. Distinct structural changes are connected with the period preceding lipotubuloid disintegration.

\section{Lipotubuloids at the stage of formation and growth}

Observations of the fine structure of cells in which lipotubuloids have not yet formed, and the osmiophilic granules are dispersed or form small groups of two to three, were made only in an electron microscope with low resolving power. Single microtubules are not visible on these micrographs, it remains, therefore, unclarified whether the osmiophilic granules are surrounded by microtubules before the lipotubuloid is formed or else whether these granules become connected with the cyto- 
plasmic microtubules at the moment when aggregations are formed. Bundles of microtubules, localized close to the plasmalemma (tangentially slanting section), running in various directions and intersecting each other are visible in fig. 2 . On these pictures, no microtubules can be distinguished, close to the osmiophilic granules. They are however, distinctly seen on pictures showing a small lipotubuloid consisting of a dozen or so osmiophilic granules in cells from the same developmental stage. Microtubules surround osmiophilic granules in the same way as they do in the lipotubuloids of all subsequent stages (fig. 9).

From the moment of lipotubuloid formation, the microtubules fixable in osmium tetroxide were observed exclusively within the lipotubuloids.

In the period of intensive increase in size of the lipotubuloids, their contours are as a rule irregular.

The cytoplasm within the lipotubuloid is characterized by profusely occurring vesicles with smooth membranes, about $300 \AA$ in size, arranged sometimes in rows. Their contents are sometimes electron-dense like the contents of the csmiophilic granules (fig. 9).

The osmiophilic granules have generally an irregular shape and are surrounded by numerous microtubules.

The size of the osmiophilic granules visible on ultrathin sections varies within wide limits as in other development stages, whereas in the light microscope all the granules seemed of more or less the same diameter of ca. $0.4 \mu$. It should be borne in mind that from one granule of this diameter one gets in 4-8 successive ultrathin sections (in dependence on their thickness and that of the first section), discs of various sizes. The question now arose, in how far is the diversity of the cross section diameters connected with the nonuniform size of the osmiophilic granules, or whether the per cent of the smaller discs may correspond to the noncentral sections of the $0.4 \mu$ granules. In search for an answer, 500 diameters of osmiophilic granules from lipotubuloids from three development phases (fig. 12A) were measured on electron micrographs. The diameters obtained in the measurements were assigned to five size classes: 1) $0.04-0.1 \mu$; 2) $0.1-0.2 \mu$; 3) $0.2-0.3 \mu$, 4) $0.3-0.4 \mu$; 5) 0.4-0.5 $\mu$. Then the proportion of the distinguished diameter classes which could be theoretically obtained by statistical calculation of parallel sections from a sphere $0.4 \mu$ in diameter, was established (These proportions correspond to those of the $A B: B C: C D: C O$ segments laid off in fig. 12B).

Comparison of the diagrams in Fig 12A shows that the size distribution obtained from measurements differs widely from the theoretically calculated value, and this leads to the conclusion that the sizes of the osmiophilic granules in each of the phases analysed are not uniform. In view of these results one may suppose that the osmiophilic granules population of the lipotubuloid varies in size within the limits of 0.04$-0.5 \mu$.

Moreover, in the phase of growth of the lipotubuloid, the number of osmiophilic granules of small dimensions $(0.04-0.1 \mu)$ constitutes 19 per cent of the population, thus, it is much higher than in other development stages (cf. fig. 12A, I, II, III). 


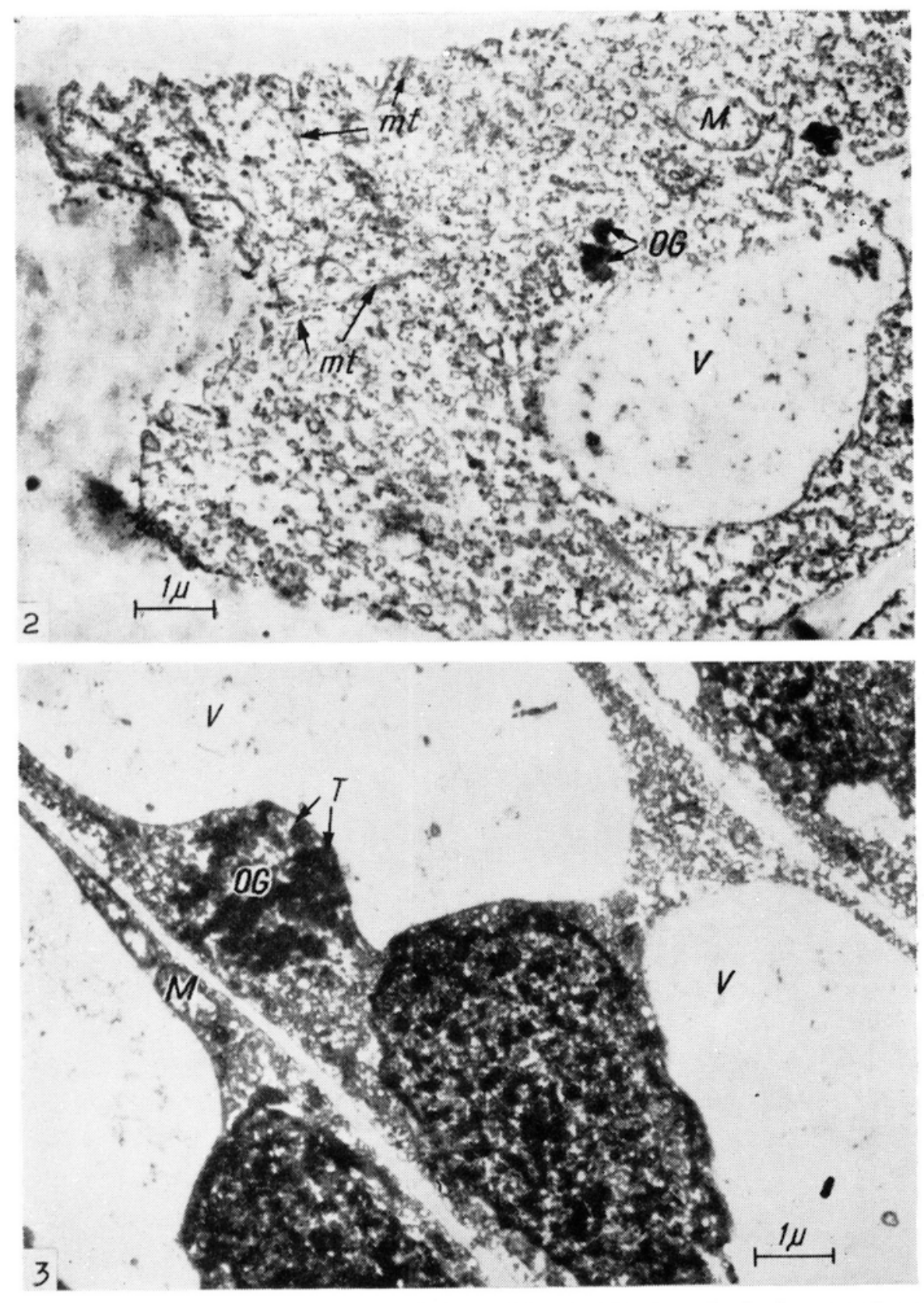

Figs 2 and 3. Ovary epidermis in O. umbellatum. Lipotubuloids in early development phases (corresp. to fig. 1A):

2 - cell fragment with osmiophilic granules forming small groups; bundles of microtubules localized in cytoplasm close to the plasmalemma, 3 - lipotubuloid of small dimensions 


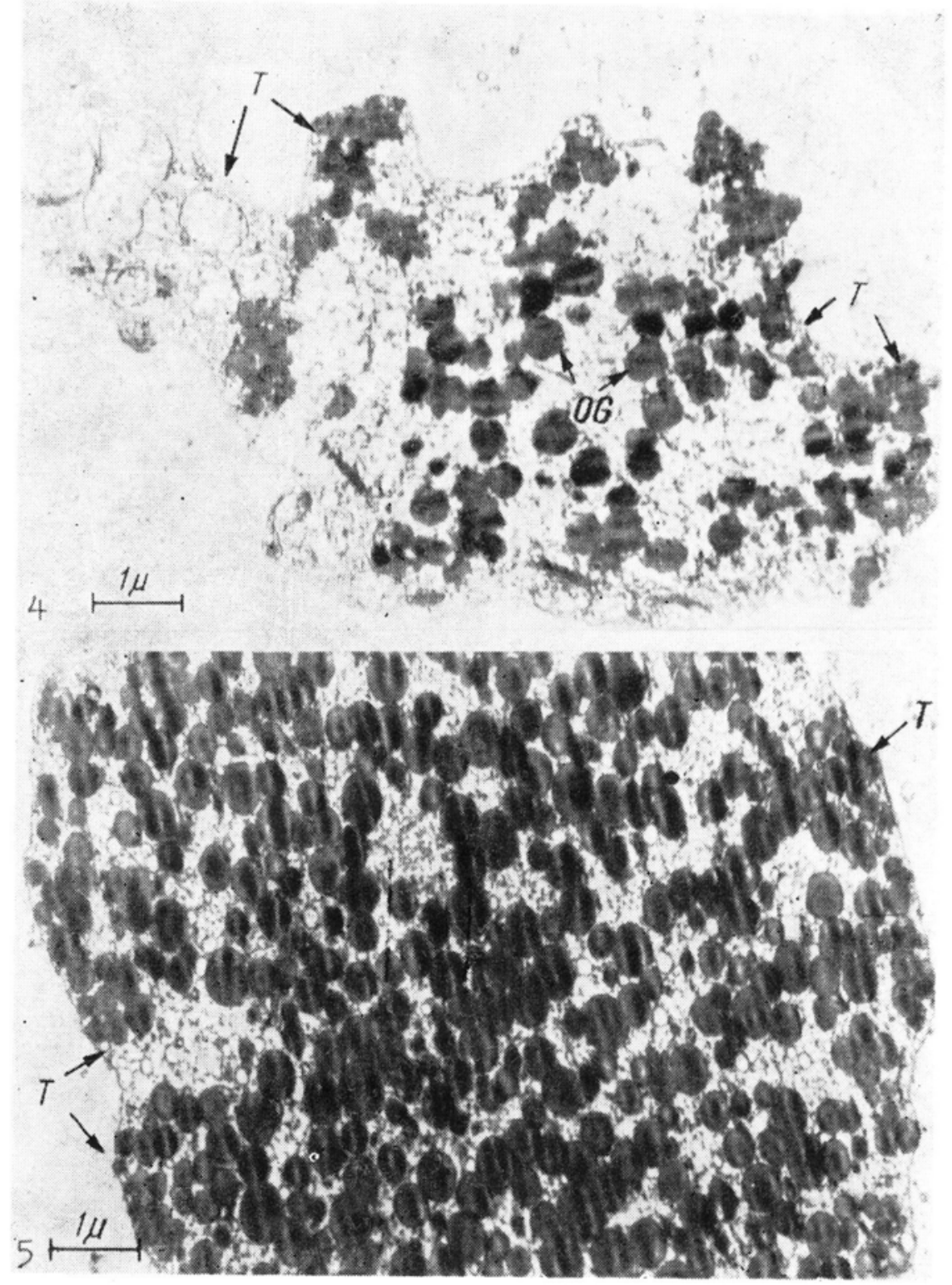

Figs 4 and 5. O. umbellatum: 4-irregular lipotubuloids in phase of growth, 5-spherical lipotubuloid. Fixation and notations as in figs 2 and 3. 

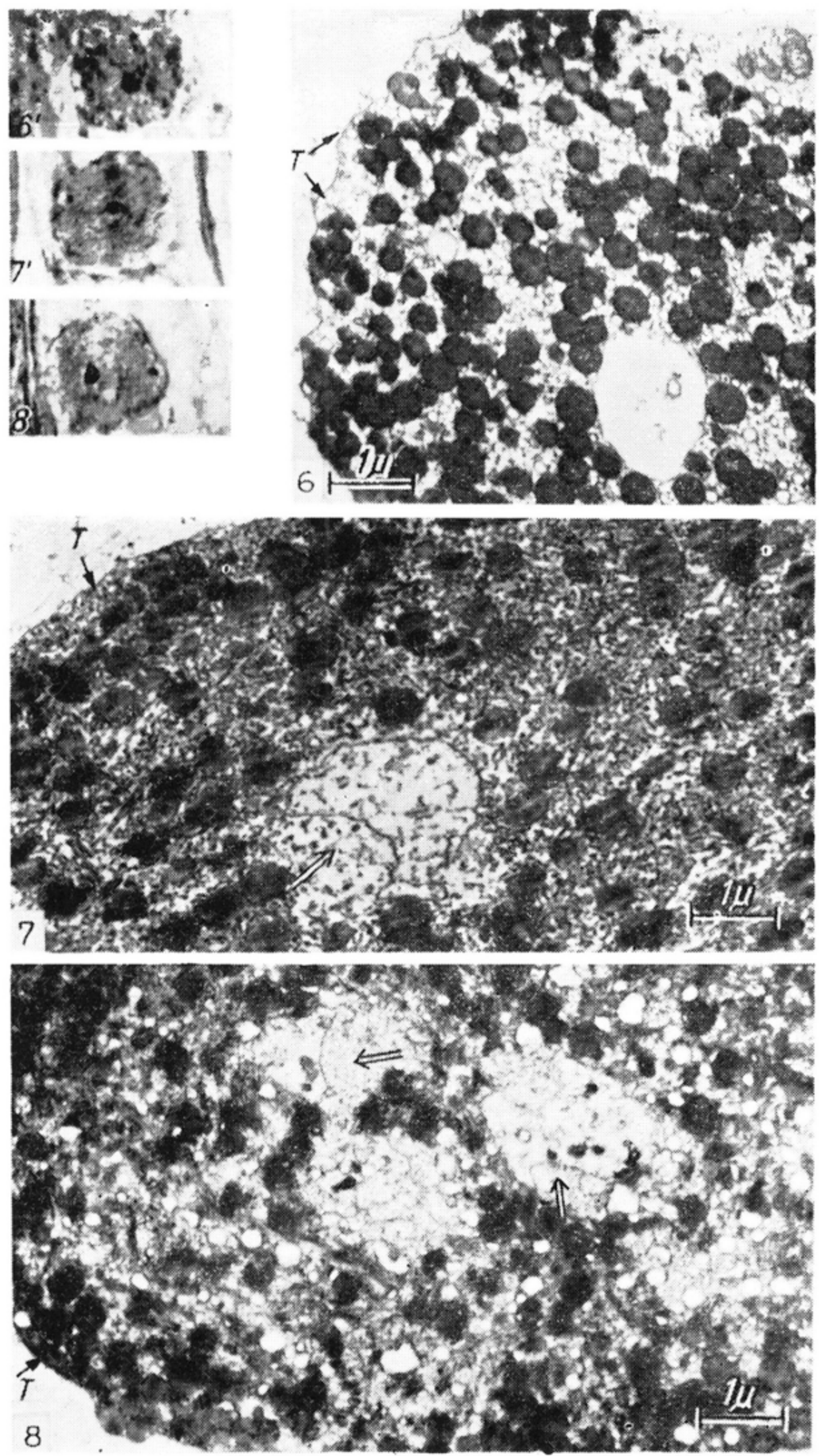

Figs 6, 7 and 8 . Lipotubuloids with autolytic vacuoles in central palt.

Fixation and notations as in preceding figures. The site of probable hydrolytic enzyme localization is marked

Figs $6^{\prime}, 7^{\prime}$ and $8^{\prime}-$ Vacuolized lipotubuloids in which activity of hydrolytic enzymes was revealed: $6^{\prime}$ and $7^{\prime}-$ lipases. $8^{\prime}-$ acid phosphatase after Burstone (Kwiatkowska, 1966). $\times 1000$ 

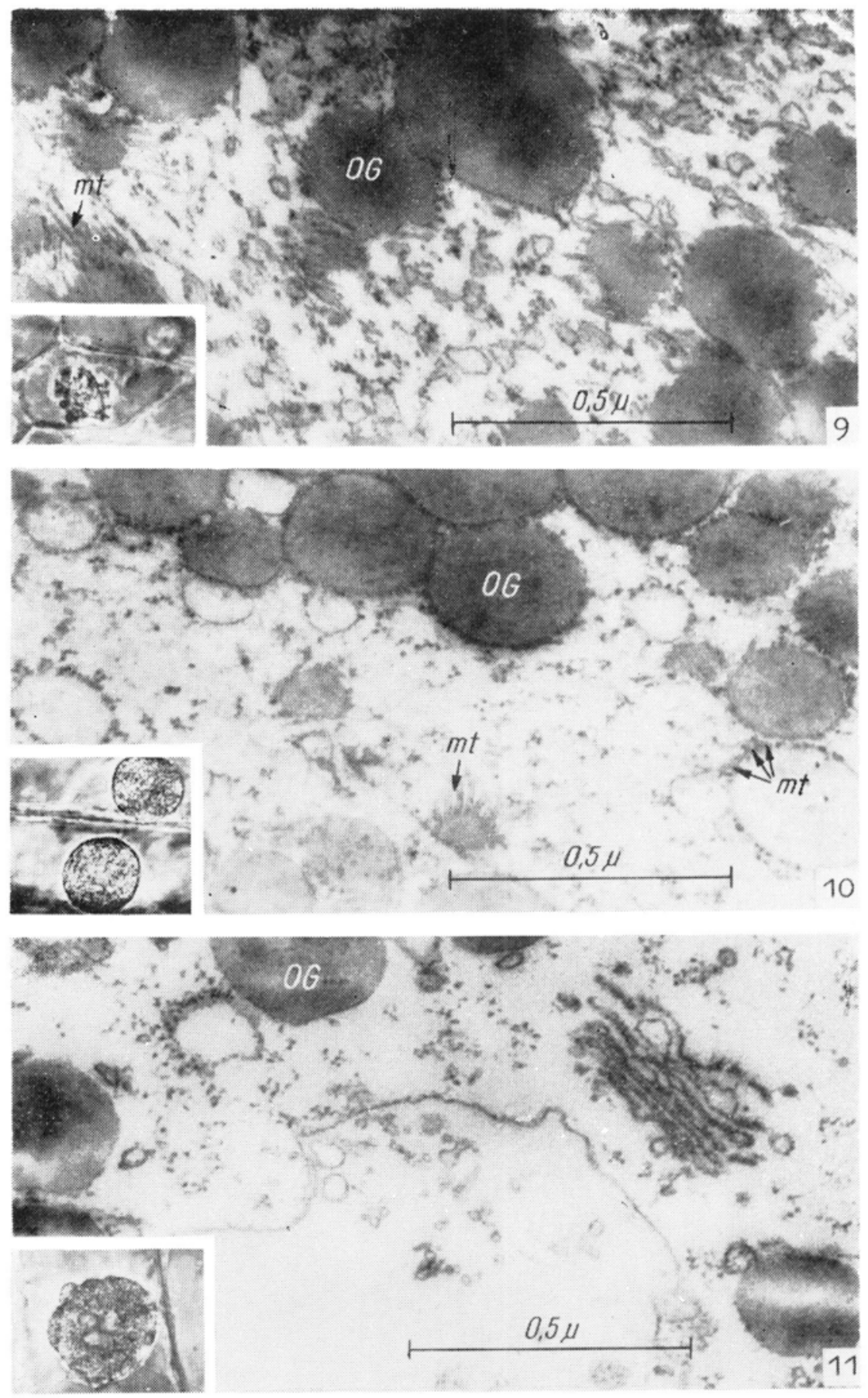

Figs 9, 10 and 11. Fine structure of lipotubuloids as compared with intra vitam pictures of lipotubuloids in three phases of development

9 - in phase of intensive growth, 10 - in spherical phase, $11-$ in phase of vacuolizations. Fixed after Palade (methacrylats) stained with uranyl acetate, photographed in UMW 100 microscope. Intravital micrographs $\times 1000$ 

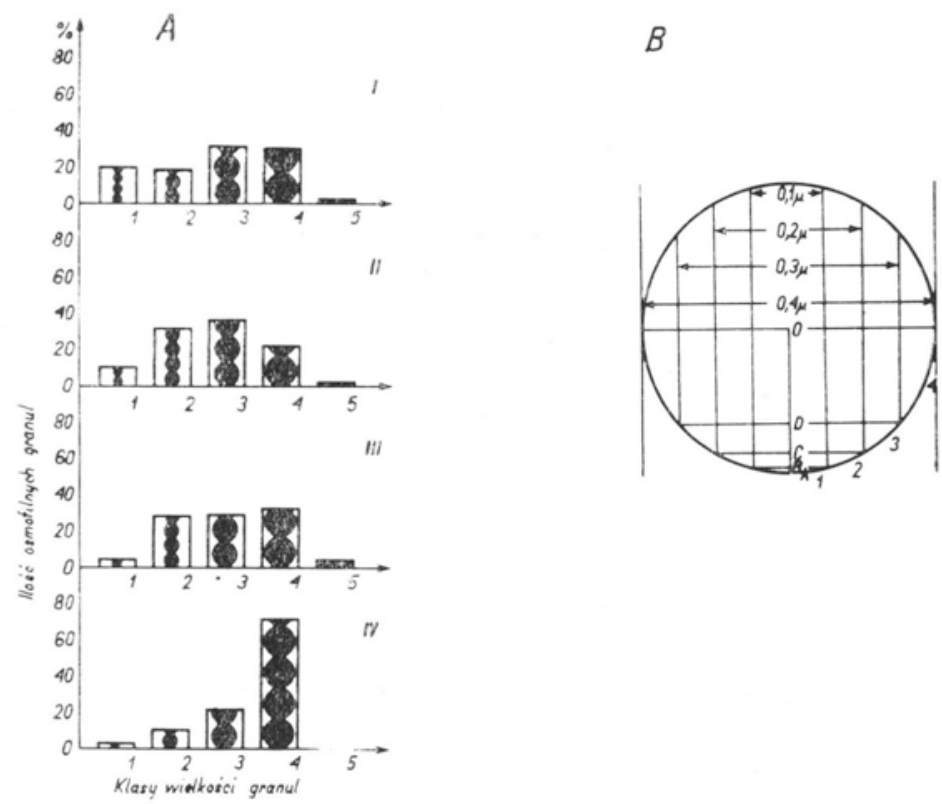

Fig. 12. O. umbellatum. Diagram illustrating the size of the osmiophilic granule populations in the established size classes at various stages of lipotubuloid development:

I - irregular lipotubuloids, II - spherical lipotubuloids, III - vacuolised lipotubuloids in stage of starting disintegratiou to single granules, IV - mathematically calculated proportions of disc of the established five size classes which could be theoretically obtained from a sphere $0.4 \mu$ in diameter when sectioned by parallel planes (equal to the proportions of the segments $A B: B C: C D: D O$ laid off in fig. 12B). The following size classes of osmiophilic granules were distinguished: 1. $0.04-0.1 \mu, 0.1-0.2 \mu, 0.2-0.3 \mu, 0.3-0.4 \mu, 0.4-0.5 \mu$

\section{Lipotubuloids in the spherical stage}

The lipotubuloids occurring in the ovary epidermis of developed flowers differ at first from the previously described ones only be their almost ideally spherical shape and larger dimensions. As the ovary enlarges and transforms to the fruit, there occur changes in the fine structure of the lipotubuloids: in the cytoplasm within the lipotubuloid the minute smooth reticulum vesicles disappear, the percentage of osmiophilic $0.04-0.1 \mu$ granules diminishes from 19.5 to 10.0 per cent. There appear electron-transparent vesicles, not found in the previous stage, surrounded with a single membrane, of a size close to that of the osmiophilic granules (figs. 8 and 10). To the outer membrane of some these vesicles more or less numerous ribosomes are attached, other vesicles are smooth. Some of the empty vesicles are surrounded by microtubules as are the osmiophilic granules (fig. 10). Sometimes a direct connection between the vesicle lumen and the microtubules is visible. It seems probable that some of these vesicular structures, at least those connected with microtubules, arose from osmiophilic granules owing to the disappearance of the electron-dense contents. 


\section{Process of lipotubuloid vacuolization and disintegration}

The early stages of vacuole formation fall to the period of appearance of the above discussed electron-transparent vesicles and sometimes vacuolization precedes this phase.

Vacuoles are formed in the epidermal cells of the greatly enlarged ovary after drying up of the perianth. Intravital and cytoenzymatic observations demonstrated that vacuolization is associated with the disappearance of the osmiophilic granules in the central part of the lipotubuloid. This process occurs simultaneously with a pronounced acid phosphatase and lipase activity (Kwiatkowska, 1966). In larger vacuoles the product of enzymatic reaction is localized on their periphery (figs $7^{\prime}, 8^{\prime}$ ).

On the electron micrographs of lipotubuloids at this stage, smaller and larger vacuoles surrounded by a single membrane are seen between the osmiophilic granules. Their localization and shape correspond to the vacuoles observed in the light microscope (cf. figs. $6^{\prime}-8^{\prime}$ and figs 6-8). Generally, in these vacuoles fragments of various structures occur: deformed osmiophilic granules, minute vesicles and membranes (Figs 6-8, 11). Also in the disintegrating lipotubuloids in which the central vacuole disappears, vacuoles containing destroyed structures can be distinguished in the groups of osmiophilic granules. On the periphery of some vacuoles, the vacuole membrane bends inward forming a concavity (figs 7 and 8 ). If we confront these pictures with the above described distribution of the coloured product of enzymatic reaction at the light miscroscope level, it would seem that it is in this concavity that the process of hydrolysis occurs leading to an enlargement of the vacuole.

In lipotubuloids occurring in ovary epidermis cells, which haved ended their growth and lose their green colour, vacuoles occupy a considerable space. In the next stage, the processes of formation of convexities on the surface (budding) and disintegration of the lipotubuloid start. A fine structure detail of the lipotubuloid specific for this period is the absence of microtubules around the osmiophilic granules and in the spaces between them (fig. 11). The absence of microtubules between which the osmiophilic granules are as if entrapped in the lipotubuloid seems to be connected with the dispersion of the lipotubuloid granules which starts at this stage. A second characteristic for lipotubuloids in the phase preceding their disintegration for lipotubuloids in the phase preceding their disintegration is the small number (hardly $4 \%$ ) of granules of $0.04-0.1 \mu$ dimensions. This value is very close to the statistically calculated number of cross sections of this size for a sphere with a $0.4 \mu$ radius cut into sections $600 \AA$ thick (fig. $12 \mathrm{a}$ ).

\section{DISCUSSION}

Comparison of the vital cycle of cells in which lipotubuloids occur with the development of the latter indicates that lipotubuloids of $O$. umbellatum are associated with the phase of cell elongation. This is particularly pronounced in the epidermis 
of the ovary and of the developing fruit. In these cells, the largest spherical lipotubuloids occur in the period of most intensive growth of the cells, and their disintegration falls to the period when the cells cease to enlarge. The existence of some relation between the life span of the lipotubuloid and elongation growth of the cells seems to be confirmed by the disappearance of lipotubuloids in the stomata much earlier than in the neighbouring epidermal cells, this being possibly connected with their reaching their final dimensions earlier.

The heterogeneous complex known as lipotubuloid arises in the period of high cell activity finding its reflection in intensive growth.

In earlier literature dealing with elaioplasts, the view prevailed that the role of elaioplasts consists in lipid production. This is no doubt correct as regards the elaioplasts which are functioning plastides (e.g. the elaioplasts described by Faul, 1935 in Iris sp.). The part played by other categories of elaioplasts including those of $O$. umbellatum, is not so clear. Certain suggestions may be advanced on the basis of observation of the development cycle of lipotubuloids.

And so, the increase of the lipotubuloid size with development of the ovary epidermis cells, which occurs by way of increase in the number of osmiophilic granules within the lipotubuloid might be considered as one of the manifestations of lipid synthesis. The question, however, arises whether this process takes place by way of new osmiophilic granules formation in the lipotubuloid or whether it represents only aggreagtions of granules which formed outside this structure. Intra vitam investigations showed an incessant attachement to and detachement from the lipotubuloid of these granules (Kwiatkowska, 1966). The prevalance of the former process may be decisive for the growth of the lipotubuloid. The present results, however, obtained in the electron microscope seem to indicate that the granules may also be formed in lipotubuloids in situ. This supposition is based on the results of measurement of the diameter of the osmiophilic granules at various stages of lipotubuloid development, which show that small granules $(0.04-0.1 \mu)$ are more numerous in young enlarging lipotubuloids than at later stages. This is probably due to the enlargement of the small osmiophilic granules to dimensions close to $0.3-0.4 \mu$ with simultaneous inhibition of the process of formation of new smallsized osmiophilic granules. The latter thus seem to be juvenile forms of the larger ones.

The presence in young lipotubuloids of numerous vesicles of smooth endoplasmic reticulum with sometimes homogeneous contents not found in older lipotubuloids, suggests that these vesicles may be the earliest initial phases of osmiophilic granules.

Lipotubuloids are also the site of lipid decomposition. This is indicated by the observation of older lipotubuloids in which vacuoles arise. This vacuolization is associated with the disappearance of the osmiophilic granules in the central part of the lipotubuloids. This process takes place under the influence of hydrolytic enzymes contained in the lipotubuloids. Acid phosphatase and lipase activity were revealed within the forming vacuoles. Observations of the fine structure at this stage of lipotubuloids indicate that the arising vacuoles are of the character of cytolysomes or autolytic vacuoles. They are surrounded by a single membrane and they contain deformed osmiophilic granules, minute vesicles and fragments of various cellular 
structures (cf. Poux 1963 Matile et al., 1965; Deysson and Benbadis, 1966; Mikulska et al., 1969). The vacuoles in the lipotubuloids increase in size, probably like the animal cell cytolysomes (cf. Napolitano, 1963), that is by encompassing and absorbing new areas in which hydrolysis occurs, as shown by the picture of the vacuole in the electron microscope and by the localization of the enzymatic reaction products on the periphery of the vacuoles (cf. figs 6 and 7 and figs $7^{\prime}$ and $8^{\prime}$ ).

The appearance of vacuoles and autolysis of the lipotubuloids are connected with the ageing of cells and the limited supply of nutrient substances to them, as shown by experimental starving of the plants by placing cut inflorescences in a vessel with water in the dark for several days.

It is probable that the processes of synthesis and hydrolysis are not limited to the formation of new osmiophilic granules in the phase of enlargement of the lipotubuloid and to autolysis of the central part of the lipotubuloids in the end phase of their development during vacuolization. It is quite possible that both synthesis and hydrolysis of lipids continuously occur in the lipotubuloids. The activity of the hydrolytic enzymes could, namely, be revealed at all phases of the development cycle of the lipotubuloids. Observations of lipotubuloid with the use of tritium-labelled palmitic acid point to a high activity of these structures in lipid synthesis processes (Kwiatkowska, in preparation).

Investigations on the changes in the fine structure of lipotubuloids, connected with their ageing throw also some light on the function of microtubules in the lipotubuloids. It was found that the microtubules forming a system of interconnections between the osmiophilic granules disappear in the pericd preceding lipotubuloid disintegration to single granules. The microtubules thus have the function of a kind of skeleton supporting the whole structure. It is also supposed that the microtubules constitute at the same time a conducting system involved in the translocation of various substances within the lipotubuloid. For instance, it would seem that the enzymes contained in some few of the lipotubuloid granules may be distributed within it by means of the microtubular system. The role of microtubules in enzyme transport is also pointed out by other authors (e.g. Journey, 1964; Boler and Arhelger, 1966).

The final determination of the function of lipotubuloids and the microtubules contained in them is as yet not possible on the basis of up to date results.

\section{SUMMARY}

Changes in the fine structure of lipotubuloids in Ornithogalum umbellatum connected with their development were investigated.

1) In young enlarging lipotubuloids of irregular shape, the osmiophilic granules of small dimensions (400-1000 $\AA$ ) constitute about 19 percent of the granule population. The cytoplasm contains numerous smooth reticulum vesicles.

2) In spherical lipotubuloids small osmiophilic granules are less numerous (ca. 10\%), the number of reticulum vesicles is also lower, there appear on the other hand, previously absent electron-transparent bodies of the size of the osmiophilic granules. 
3) In the spherical stage, autolytic vacuoles start to form in the centre of the lipotubuloid surrounded by a membrane and containing the destroyed cellular elements - minute vesicles, fragments of membranes, deformed osmiophilic granules. These vacuoles correspond to the vacuoles exhibiting hydrolase activity seen in the light microscope.

4) In highly vacuolized lipotubuloids which begin to disintegrate to single granules no microtubules were found. In this phase osmiophilic granules constitute about 4.5 per cent of the population.

\section{REFERENCES}

Boler R. K., Arhelger R. B., 1966, Microtubules in cytosomes and cytosegresomes of rabbit proximal tubule epithelium, Lab. Investig. 15: 302-311.

Deysson G., Ben badis M.C., 1966, Sur la formation de cytolysomes dans les cellules des méristèmes radiculaires d'Allium sativum, J. Micr. 5: 420.

Faull A., 1935, Elaioplasts in Iris, J. Arnold Arbor. 16: 225-267.

Journey L. J., 1964, Cytoplasmic microtubules in mouse peritoneal macrophages during rejection of MC1M ascites tumor cells, Cancer Research 24: 1391-1405.

Kwiatkowska M., 1962, Elajoplasty roślin kwiatowych. Rozpr. dokt. U.Ł.

Kwiatkowska M., 1966, Investigations on the elaioplasts of Ornithogalum umbellatum L. Acta, Soc. Bot. Pol. 35: 7-16.

Kwiatkowska M., 1971, Fine structure of the lipotubuloids (elaioplasts) in Ornithogalum umbellatum P. I. Acta Soc. Bot. Pol. 40: 451-465.

Matile Ph., Balz J., Semadeni E., Jost M., 1965, Isolation of spherosomes with lysosome characteristics from seedlings, Zeit. f. Naturf. 20: 693-698.

Mikulska E., Żołnierowicz H., Wałek-Czernecka Ą., 1969, Ultrastruktura warstwy wyściełającej i periplazmodium w pylnikach Larix decidua Mill., Acta Soc. Pol. 38: 201-301.

Napolitano L., 1963, Cytolysomes in metabolically active cells, J. Cell Biol. 18: 478-481.

Politis J., 1911, Sugli Elaioplasti nelle Mono-e Dicotiledoni, Att. Ac. Lincei 20: 599-603.

Poux N., 1963, Sur la présence d'enclaves cytoplasmiques en voie de dégénérescence dans les vacuoles des cellules végétales, C.r. Acad. Sci. 257: 736-738.

Raciborski M., 1895, Elajoplasty liliowatych, Rozpr. Ak. Um. Mat. Przyr. S II, 6.

\section{Ultrastruktura lipotubuloidów (elajoplastów) Ornithogalum umbellatum w różnych fazach rozwoju}

\section{Streszczenie}

Prześledzono zmiany ultrastruktury lipotubuloidów śniedka związane z ich rozwojem.

1) W młodych, zwiększających rozmiary lipotubuloidach o nieregularnych kształtach granule osmofilne o małych wymiarach (od $400 \AA$ do $1000 \AA$ ) stanowią około $19 \%$ populacji granul. Cytoplazma zawiera liczne pecherzyki gładkiego retikulum.

2) W lipotubuloidach kulistych mniejsze granule osmofilne są mniej liczne (ok. 10\%), zmniejsza się także ilość małych pęcherzyków retikulum, zjawiają się zaś przepuszczalne dla elektronów utwory wielkości osmofilnych granul, których nie było w poprzednim stadium.

3) W stadium sferycznym rozpoczyna siẹ także tworzenie w centrum lipotubuloidów wakuol autolitycznych otoczonych membraną i zawierających zniszczone elementy - drobne pẹcherzyki, fragmenty membran, zdeformowane osmofilne granule. Wakuole te odpowiadają widocznym w mikroskopie świetlnym wakuolom wykazującym aktywność hydrolaz.

4) W lipotubuloidach silnie zwakuolizowanych, które zaczynają się rozpraszać na pojedyncze granule, nie stwierdzono obecności mikrotubul. W tej fazie najmniejsze osmofilne granule stanowią tylko ok. $4,5 \%$ populacji. 